https://doi.org/10.52449/1857-4114.2021.37-1.04

CZU: 796.15:355/359

\title{
INTENSIFICATION OF THE PROFESSIONAL-APPLICATIVE PHYSICAL TRAINING PROCESS OF MILITARY FIREFIGHTERS
}

\author{
Loluţă Adrian-Gabriel', ORCID: 0000-0002-1219-1452 \\ ${ }^{1}$ Inspectorate for Emergency Situation "N. Iorga” MIA, Botosani, Romania
}

\begin{abstract}
The general, specific and specialized physical training determines the level of development of the motor possibilities of the personnel, reached in the process of the systematic practice of the professional-applicative physical exercises.

The problem solved in this research was to identify new ways to intensify the professionalapplied physical training of the operative personnel, military personnel within the intervention subunits of the Inspectorate for Emergency Situations.

The study was conducted over a period of 2 months (May-June 2019) on the field / training plateau of the Botosani and Dorohoi Fire Brigade and had as subjects a sample of 10 noncommissioned officers (military personnel) who took two individual tests: with/without a respirator device. The research methods: the study of the specialized literature, the direct observation, the experiment, the comparison, the statistical-mathematical analysis. Ways to test the physical capacity, the type of effort made (aerobic, anaerobic) in one or more motor actions are numerous and at the same time, very demanding, necessary for the special device and a larger study.

During the experiment there was a reduction in time but also an increase in motor potential at the unit stage (initial testing), as well as obtaining the honorable 3rd place in the national phase (final testing) of the contest "The most powerful firefighter" Alba-Iulia, 2019 edition, of the noncommissioned officers from the Inspectorate for Emergency Situations "Nicolae Iorga" of Botosani.

Following some application routes with a high degree of difficulty, we can say that it must be customized in this activity has significantly improved their motor skills.
\end{abstract}

Keywords: firefighters, route, evaluation, military personnel, running, stages.

Introduction. The specialized physical training of the military firefighters within the Inspectorate for Emergency Situations "Nicolae Iorga" of Botosani must ensure the increase of motor capacity of the personnel, as well as the harmonization of teamwork, by going through circuits, individually or as a team, developing the skills necessary to perform specific techniques and maneuvers [10].

To increase the prestige of the General Inspectorate for Emergency Situations (I.G.S.U.), at national level is organized annually the contest "The Strongest Firefighter", a competition dedicated to military firefighters (officers, foremen, non- commissioned officers) organized with the help of the Romanian Sports Firefighters Association (A.S.P.R.) and the Romanian C.T.I.F. Association [5].

The purpose of this research was to identify new ways to intensify the process of professional-applied physical training of operational staff in professional structures for emergencies within the subunits.

The research objectives:

$>$ developing and improving the specific skills and abilities necessary to perform emergency intervention actions;

evaluation of the level of preparation of the intervention capacity of the professional services for emergency situations; 
popularizing, among the citizens, some aspects of the activities carried out by the military firefighters.

Research methods. The study was conducted over a period of 2 months (MayJune 2019) on the training ground / board of the Botoşani and Dorohoi Fire Detachment and had as a subject a sample of 10 noncommissioned officers (military personnel) [8].
They had to bear two individual samples: with breathing apparatus and without breathing apparatus, related to the scales and notes according to Table 1 .

The research methods used are: studying the specialized literature, direct observation, experiment, comparison, statisticalmathematical analysis [2].

Table 1. The scales established for the checks on the motor circuit

\begin{tabular}{|c|c|c|c|c|}
\hline $\begin{array}{l}\text { Performance / } \\
\text { time - min. }\end{array}$ & Basic note & \multicolumn{3}{|c|}{ Note / Rating / Pulse } \\
\hline-3.00 & 10 & $10 /$ Ex. $/<170$ & $9.75 / \mathrm{FB} / 170-180$ & 8.75 / B / > 180 \\
\hline $3.00-3.10$ & 9,75 & $9,75 / \mathrm{FB} /<170$ & $8,75 / \mathrm{B} / 170-180$ & 7,75 / B / > 180 \\
\hline $3.11-3.20$ & 9,50 & $9,50 / \mathrm{FB} /<170$ & 8,50 / B / 170 - 180 & 7,50 / B / > 180 \\
\hline $3.21-3.30$ & 9,25 & $9,25 / \mathrm{FB} /<170$ & 8,25 / B / $170-180$ & 7,25 / B / > 180 \\
\hline $3.31-3.40$ & 9,00 & $9,00 / \mathrm{FB} /<170$ & $8,00 / \mathrm{B} / 170-180$ & $7,00 / \mathrm{B} />180$ \\
\hline $3.41-3.50$ & 8,75 & $8,75 / \mathrm{B} /<170$ & 7,75 / B / $170-180$ & $6,75 / \mathrm{C} />180$ \\
\hline $3.51-4.00$ & 8,50 & $8,50 / \mathrm{B} /<170$ & $7,50 / \mathrm{B} / 170-180$ & $6,50 / \mathrm{C} />180$ \\
\hline $4.01-4.10$ & 8,25 & $8,25 / \mathrm{B} /<170$ & $7,25 / \mathrm{B} / 170-180$ & $6,25 / C />180$ \\
\hline $4.11-4.20$ & 8,00 & $8,00 / \mathrm{B} /<170$ & $7,00 / \mathrm{B} / 170-180$ & $6,00 / \mathrm{C} />180$ \\
\hline $4.21-4.30$ & 7,75 & $7,75 / \mathrm{B} /<170$ & $6,75 / \mathrm{C} / 170-180$ & $5,75 / \mathrm{M} />180$ \\
\hline $4.31-4.40$ & 7,50 & $7,50 / \mathrm{B} /<170$ & $6,50 / \mathrm{C} / 170-180$ & $5,50 / \mathrm{M} />180$ \\
\hline $4.41-4.50$ & 7,25 & $7,25 / \mathrm{B} /<170$ & $6,25 / \mathrm{C} / 170-180$ & $5,25 / \mathrm{M} />180$ \\
\hline $4.51-5.00$ & 7,00 & $7,00 / \mathrm{B} /<170$ & $6,00 / \mathrm{C} / 170-180$ & $5,00 / \mathrm{M} />180$ \\
\hline $5.01-5.10$ & 6,75 & $6,75 / \mathrm{C} /<170$ & $5,75 / \mathrm{M} / 170-180$ & $4,75 / \mathrm{NC} />180$ \\
\hline $5.11-5.20$ & 6,50 & $6,50 / \mathrm{C} /<170$ & $5,50 / \mathrm{M} / 170-180$ & $4,50 / \mathrm{NC} />180$ \\
\hline $5.21-5.30$ & 6,25 & $6,25 / \mathrm{C} /<170$ & $5,25 / \mathrm{M} / 170-180$ & 4,25 / $\mathrm{NC} />180$ \\
\hline $5.31-5.40$ & 6,00 & $6,00 / \mathrm{C} /<170$ & $5,00 / \mathrm{M} / 170-180$ & $4,00 / \mathrm{NC} />180$ \\
\hline $5.41-5.50$ & 5,75 & $5,75 / \mathrm{M} /<170$ & $4,75 / \mathrm{NC} / 170-180$ & $3,75 / \mathrm{NC} />180$ \\
\hline $5.51-6.00$ & 5,50 & $5,50 / \mathrm{M} /<170$ & $4,50 / \mathrm{NC} / 170-180$ & $3,50 / \mathrm{NC} />180$ \\
\hline $6.01-6.10$ & 5,25 & $5,25 / \mathrm{M} /<170$ & $4,25 / \mathrm{NC} / 170-180$ & $3,25 / \mathrm{NC} />180$ \\
\hline $6.11-6.20$ & 5,00 & $5,00 / \mathrm{M} /<170$ & $4,00 / \mathrm{NC} / 170-180$ & $3,00 / \mathrm{NC} />180$ \\
\hline $6.21-$ & $1,00-4,99$ & $4,75 / \mathrm{NC} /<170$ & $3,75 / \mathrm{NC} / 170-180$ & $2,75 / \mathrm{NC} />180$ \\
\hline $\begin{array}{c}\text { Grid for convert } \\
\cdot \text { Except } \\
\cdot \text { Very G } \\
\cdot \text { Good } \\
\cdot \text { Corres } \\
\cdot \text { Mediu } \\
\cdot \text { Non-An }\end{array}$ & $\begin{array}{r}-B= \\
\text { dent }-C= \\
-M= \\
-N C=\end{array}$ & $\begin{array}{l}\text { alifiers: } \\
0 \\
9.00-9.99 \\
00-8.99 \\
00-6.99 \\
.00-599 \\
00-4.99\end{array}$ & $\begin{aligned} & \text { Ruffier Index: } \\
& \text { Very G } \\
& \text { Good (I } \\
& \text { Mediun } \text { Satisfa } \\
& \text { Unsat }\end{aligned}$ & $\begin{array}{l}\text { od }(\mathrm{FB})<1 \text {; } \\
1-5 ; \\
\text { (M) } 5-10 \\
\text { ory (S) } 10-15 ; \\
\text { factory }(\mathrm{NS})>15 \text {. }\end{array}$ \\
\hline
\end{tabular}

Findings and results. The ways to test the physical capacity, the type of effort made (aerobic, anaerobic) [1] in one or more motor actions are numerous and at the same time, very demanding, requiring special equipment and a larger study [3].

During the experiment there was a reduction of the time duration but also an increase of the motor potential at the unit stage 
(initial testing), as well as obtaining the honorable place 3 at the national phase (final testing) of the contest "The most powerful fireman", 2019 edition , which took place in the municipality of Alba-Iulia, between 1821.06.2019, of the non-commissioned officers of the Inspectorate for Emergency Situations "Nicolae Iorga" of Botosani.

1. Development of the circuit: Sample No. 1 - with breathing apparatus.

Competitor's equipment: protective suit for firefighters, sports shoes, protective gloves (extinguishing or unloading), protective helmet (extinguishing) and mask with compressed air breathing apparatus, with a minimum pressure of $200 \mathrm{bar}$.

1. Run $5 \mathrm{~m}$ up to two 201 canisters that they carry around the metal device (about 20 $\mathrm{m})$ and back and place them in the marked place.

2. Running $20 \mathrm{~m}$ to the $6 \mathrm{~kg}$ bar with which it hits 100 times in the metal device, after which it places the bar in the established place.

3. Running $20 \mathrm{~m}$, lifting a discharge pipe and connecting it to a fixed connection (motor pump).
4. Travel $5 \mathrm{~m}$ to a type $\mathrm{B}$ hose on the ground which must be rolled in a single roller and transported $20 \mathrm{~m}$ to the special vehicle and placed in the designated place (the hose must be rolled so that it can be inserted in the car seat)

5. Zigzag movement about $7 \mathrm{~m}$, crossing the milestones $(5 \mathrm{~m}$ distance between them with a width of $3 \mathrm{~m}$ ), lifting the first type $\mathrm{B}$ hose roller, transporting it back among the milestones and depositing it in the car seat.

6. Zigzag movement about $7 \mathrm{~m}$, crossing the milestones $(5 \mathrm{~m}$ distance between them with a width of $3 \mathrm{~m}$ ), lifting the second type $B$ hose reel, transporting it back among the milestones and depositing it in the car's special bench.

7. Run $5 \mathrm{~m}$, lift an intervention ax and attach its blade to the stem.

8. Run 10 m until arrival.

Note: The competitor is fully equipped and wears a respirator with compressed air mask. The evaluator checks the pressure in the cylinder (minimum 200 bar).

Table 2. Training and evaluation circuit samples: sample 1 - with breathing apparatus

\begin{tabular}{|c|c|c|c|c|}
\hline $\begin{array}{c}\text { No. } \\
\text { crt. }\end{array}$ & $\begin{array}{c}\text { Name of the } \\
\text { sample }\end{array}$ & \multicolumn{1}{|c|}{ Description of the sample } & \multicolumn{1}{c|}{ Remarks } \\
\hline 1 & $\begin{array}{c}\text { EQUIPMENT } \\
\text { WITH } \\
\text { BREATHING } \\
\text { APPARATUS } \\
\text { AND MASK }\end{array}$ & $\begin{array}{l}\text { In this test, the firefighter is equipped with the breathing apparatus and } \\
\text { the air mask from the START line }\end{array}$ & $\begin{array}{l}\text { The test ends when the } \\
\text { firefighter is fully and } \\
\text { properly equipped with the } \\
\text { breathing apparatus } \\
\text { (minimum 200 bar). }\end{array}$ \\
\hline 2 & $\begin{array}{c}\text { TRANSPORT ON } \\
\text { OF TWO } \\
\text { BOTTLES OF 20 } \\
\text { LITERS }\end{array}$ & $\begin{array}{c}\text { Run } 5 \mathrm{~m} \text { up to two 20 I canisters that they carry around the metal device } \\
\text { and back and place them in the marked place. }\end{array}$ & $\begin{array}{l}\text { The non-commissioned } \\
\text { officer lifts two 20l canisters } \\
\text { and travels 20 m to the } \\
\text { metal device and back. } \\
\text { At the end of this activity, } \\
\text { sample no.3. }\end{array}$ \\
\hline
\end{tabular}




\begin{tabular}{|c|c|c|c|}
\hline $\begin{array}{l}\text { No. } \\
\text { crt. }\end{array}$ & $\begin{array}{c}\text { Name of the } \\
\text { sample }\end{array}$ & Description of the sample & Remarks \\
\hline \multirow[t]{2}{*}{3} & \multirow[t]{2}{*}{$\begin{array}{l}\text { RACING } 20 \\
\text { METERS AND } \\
\text { APPLYING } \\
\text { LOVITIES }\end{array}$} & $\begin{array}{l}\text { Run } 20 \mathrm{~m} \text { to the } 6 \mathrm{~kg} \text { bar with which it hits } 100 \text { times in the metal device, } \\
\text { after which it places the bar in the established place. }\end{array}$ & \multirow[t]{2}{*}{$\begin{array}{l}\text { The trial ends when the } \\
\text { fireman applied } 100 \text { shots } \\
\text { with the 6kg hammer. } \\
\text { Then it moves to the } \\
\text { NOVUS motor pump to start } \\
\text { the test no. } 4 \text {. }\end{array}$} \\
\hline & & $20 \mathrm{~m} \quad$ Metal device 100 strokes & \\
\hline \multirow[t]{2}{*}{4} & \multirow[t]{2}{*}{$\begin{array}{l}\text { REALIZATION } \\
\text { OF THE } \\
\text { INTERVENTION } \\
\text { DEVICE }\end{array}$} & $\begin{array}{l}\text { Running } 20 \mathrm{~m} \text {, lifting a discharge pipe and connecting it to a fixed } \\
\text { connection (motor pump). }\end{array}$ & \multirow[t]{2}{*}{$\begin{array}{l}\text { For this test, it connects a } \\
\text { type } C \text { pipe to the NOVUS } \\
\text { motor pump } \\
\text { After the completion of the } \\
\text { sample, it is prepared for the } \\
\text { beginning of the sample no. } \\
5 \text {. }\end{array}$} \\
\hline & & Start $20 \mathrm{~m} \quad$ Type C pipe $\quad 5 \mathrm{~m}$ & \\
\hline 5 & $\begin{array}{l}\text { TIGHTENING A } \\
\text { HOSE WHEEL } \\
\text { TYPE B }\end{array}$ & $\begin{array}{l}\text { Travel } 5 \mathrm{~m} \text { to a type } B \text { hose on the ground which must be rolled in a } \\
\text { single roller and transported } 20 \mathrm{~m} \text { to a special truck and placed in the } \\
\text { designated place }\end{array}$ & $\begin{array}{l}\text { The test ends when the hose } \\
\text { is inserted into the special } \\
\text { banquets of the special } \\
\text { vehicle. (the hose must be } \\
\text { rolled so that it can be } \\
\text { inserted into the car's } \\
\text { banquet) } \\
\text { The fireman continues with } \\
\text { sample no. } 6 \text {. }\end{array}$ \\
\hline 6 & $\begin{array}{l}\text { TRANSPORT } \\
\text { A } 2 \text { TYPE HOSE } \\
\text { WHEELS B }\end{array}$ & $\begin{array}{l}\text { Zig-zag movement about } 7 \mathrm{~m} \text {, crossing the milestones ( } 5 \mathrm{~m} \text { distance } \\
\text { between them with a width of } 3 \mathrm{~m} \text { ), lifting the first type } \mathrm{B} \text { hose roller, } \\
\text { transporting it back among the milestones and depositing it in the auto- } \\
\text { special banquet. }\end{array}$ & $\begin{array}{l}\text { The test ends when the non- } \\
\text { commissioned officer } \\
\text { brought the } 2 \text { type B hoses } \\
\text { and submitted them to the } \\
\text { special unit. } \\
\text { Then prepare for the } \\
\text { beginning of the trial no. } 7 \text {. }\end{array}$ \\
\hline 7 & $\begin{array}{l}\text { LIFTING AND } \\
\quad \text { FIXING } \\
\text { PSI AX }\end{array}$ & Run $5 \mathrm{~m}$, lifting an intervention ax and attaching its blade to the log. & $\begin{array}{l}\text { At this sample you lift the psi } \\
\text { ax into the wooden log. } \\
\text { At the end of this sample, } \\
\text { continue with sample no. } 8 \text {. }\end{array}$ \\
\hline
\end{tabular}




\begin{tabular}{|c|c|c|c|}
\hline $\begin{array}{c}\text { No. } \\
\text { crt. }\end{array}$ & $\begin{array}{c}\text { Name of the } \\
\text { sample }\end{array}$ & Description of the sample & Remarks \\
\hline 8 & $\begin{array}{l}\text { VICTIM } \\
\text { TRANSPORT }\end{array}$ & $\begin{array}{l}\text { arrival. } \\
\text { Ting and transporting a } 60 \mathrm{~kg} \text { manikin over a distance of } 10 \mathrm{~m} \text { until }\end{array}$ & $\begin{array}{l}\text { The circuit ends when the } \\
\text { non-commissioned } \\
\text { officer } \\
\text { crosses the finish line or at } \\
\text { least foot touches the } \\
\text { line. }\end{array}$ \\
\hline
\end{tabular}

2. Circuit unfolding: Sample No. 2 - no breathing apparatus

The competitor is fully equipped, without the breathing apparatus.

1. Run $5 \mathrm{~m}$ to 2 type $\mathrm{C}$ hoses, filled with water, which must extend $40 \mathrm{~m}$ and place the discharge pipes in the marked place.

2. Running back $40 \mathrm{~m}$ and climbing the fence $2 \mathrm{~m}$.

3. Run $5 \mathrm{~m}$ up to a $200 \mathrm{~kg}$ rubber that it must roll once.

4. Run $5 \mathrm{~m}$ and cross the "trap" dragging through the tunnel.

5. Run $5 \mathrm{~m}$ to the base of the stairs where it raises 2201 canisters - from the marked place, which it transports to the platform at the end of the stairs where they place them in the established place.

6. Lifting 2 times of 2 type B rollers connected together with the help of the rope and storing them on the platform, in the established place.

7. Lifting the two canisters and transporting them back up the stairs to the marked place, from where they were taken.

8. Lifting a manikin with the axle socket and transporting it for a distance of $20 \mathrm{~m}$ to the milestone and back.

9. Run $5 \mathrm{~m}$ and cross the "trap" - dragging through the tunnel.

10. Run $5 \mathrm{~m}$ up to a $200 \mathrm{~kg}$ rubber that he has to roll back once.

11. Run to the finish line.

Table 3. Training and evaluation circuit tests: sample 2 - without breathing apparatus

\begin{tabular}{|c|c|c|c|}
\hline $\begin{array}{c}\text { No. } \\
\text { crt. }\end{array}$ & $\begin{array}{c}\text { Name of the } \\
\text { sample }\end{array}$ & \multicolumn{1}{|c|}{ Description of the sample } & \multicolumn{1}{c|}{ Remarks } \\
\hline 1 & $\begin{array}{l}\text { TOWING 2 HOSE } \\
\text { WHEELS TYPE C } \\
\text { place the discharge pipes in the marked place. }\end{array}$ & $\begin{array}{l}\text { The test ends when the } \\
\text { firefighter places the } \\
\text { discharge pipe at the 40 } \\
\text { meter line. }\end{array}$ \\
\hline 2 & $\begin{array}{l}\text { CLIMBING THE 2 } \\
\text { METER GUARD }\end{array}$ & Running back 40 $\mathrm{m}$ and climbing the fence 2 $\mathrm{m}$. & $\begin{array}{l}\text { The non-commissioned } \\
\text { officer climbs the 2 } \\
\text { meter fence. } \\
\text { At the end of this activity, }\end{array}$ \\
\hline
\end{tabular}




\begin{tabular}{|c|c|c|c|}
\hline $\begin{array}{l}\text { No. } \\
\text { crt. }\end{array}$ & $\begin{array}{c}\text { Name of the } \\
\text { sample }\end{array}$ & Description of the sample & Remarks \\
\hline & & Fence of 2 meters & sample no. 3. \\
\hline 3 & $\begin{array}{l}\text { TURNING A } 200 \\
\text { KG RUBBER }\end{array}$ & Run $5 \mathrm{~m}$ up to a $200 \mathrm{~kg}$ rubber that he must roll once. & $\begin{array}{l}\text { In this test the fireman } \\
\text { rolls a } 200 \mathrm{~kg} \text { rubber. } \\
\text { After the completion of } \\
\text { the sample, it is } \\
\text { prepared for the } \\
\text { beginning of the sample } \\
\text { no. } 4 \text {. }\end{array}$ \\
\hline 4 & $\begin{array}{c}5 \text { METER CASS } \\
\text { TRAVEL }\end{array}$ & Run $5 \mathrm{~m}$ and cross the "trap" - drags & $\begin{array}{l}\text { The test ends when the } \\
\text { fireman crossed the } 5 \\
\text { meter tunnel. } \\
\text { Then it moves to the } \\
\text { base of the steps to start } \\
\text { the trial no. } 5 \text {. }\end{array}$ \\
\hline 5 & $\begin{array}{l}\text { TRANSPORT OF } \\
\text { TWO } \\
\text { CANISTERS OF } \\
20 \text { LITERS }\end{array}$ & $\begin{array}{l}\text { Run } 5 \mathrm{~m} \text { to the base of the stairs from where he lifts two } 201 \text { canisters - from } \\
\text { the marked place, which he transports to the platform at the end of the stairs } \\
\text { where they place them in the established place. }\end{array}$ & $\begin{array}{l}\text { The test ends when the } \\
\text { firefighter goes up and } \\
\text { down the stairs with } 220 \\
\text { liter canisters. } \\
\text { The fireman continues } \\
\text { with sample no. } 6 \text {. }\end{array}$ \\
\hline 6 & $\begin{array}{c}\text { THE RISE OF } \\
\text { TWO HOSE } \\
\text { WHEELS TYPE B }\end{array}$ & $\begin{array}{l}\text { Double lifting } 2 \text { type } \mathrm{B} \text { rollers connected together with the help of the rope } \\
\text { and storing them on the platform, in the established place. }\end{array}$ & $\begin{array}{l}\text { The test ends when the } \\
\text { non-commissioned } \\
\text { officer raised the } 2 \text { type } \\
\text { B hoses and placed } \\
\text { them on the platform. } \\
\text { Then prepare for the } \\
\text { beginning of the trial no. } \\
7 \text {. }\end{array}$ \\
\hline 7 & $\begin{array}{c}\text { VICTIM } \\
\text { TRANSPORT }\end{array}$ & Lifting and transporting a $60 \mathrm{~kg}$ manikin over a distance of $40 \mathrm{~m}$ until arrival. & $\begin{array}{l}\text { The test ends when the } \\
\text { firefighter crosses the } \\
\text { finish line or at least one } \\
\text { foot touches the line. }\end{array}$ \\
\hline
\end{tabular}


Nr. 37/1 - 2021

\begin{tabular}{|c|c|c|c|}
\hline $\begin{array}{c}\text { No. } \\
\text { crt. }\end{array}$ & $\begin{array}{c}\text { Name of the } \\
\text { sample }\end{array}$ & \multicolumn{1}{c|}{ Description of the sample } & \multicolumn{1}{c|}{ Remarks } \\
\hline 8 & $\begin{array}{c}\text { Run } 5 \mathrm{~m} \text { and cross the "trap" - dragging through the tunnel, rolling } 200 \mathrm{~kg} \\
\text { rubber, running } 5 \mathrm{~m} \text { to the finish line. } \\
\text { RUBBER }\end{array}$ & $\begin{array}{l}\text { At this test, cross the } \\
\text { trap and roll the rubber, } \\
\text { then run to the finish } \\
\text { line. }\end{array}$ \\
\hline
\end{tabular}

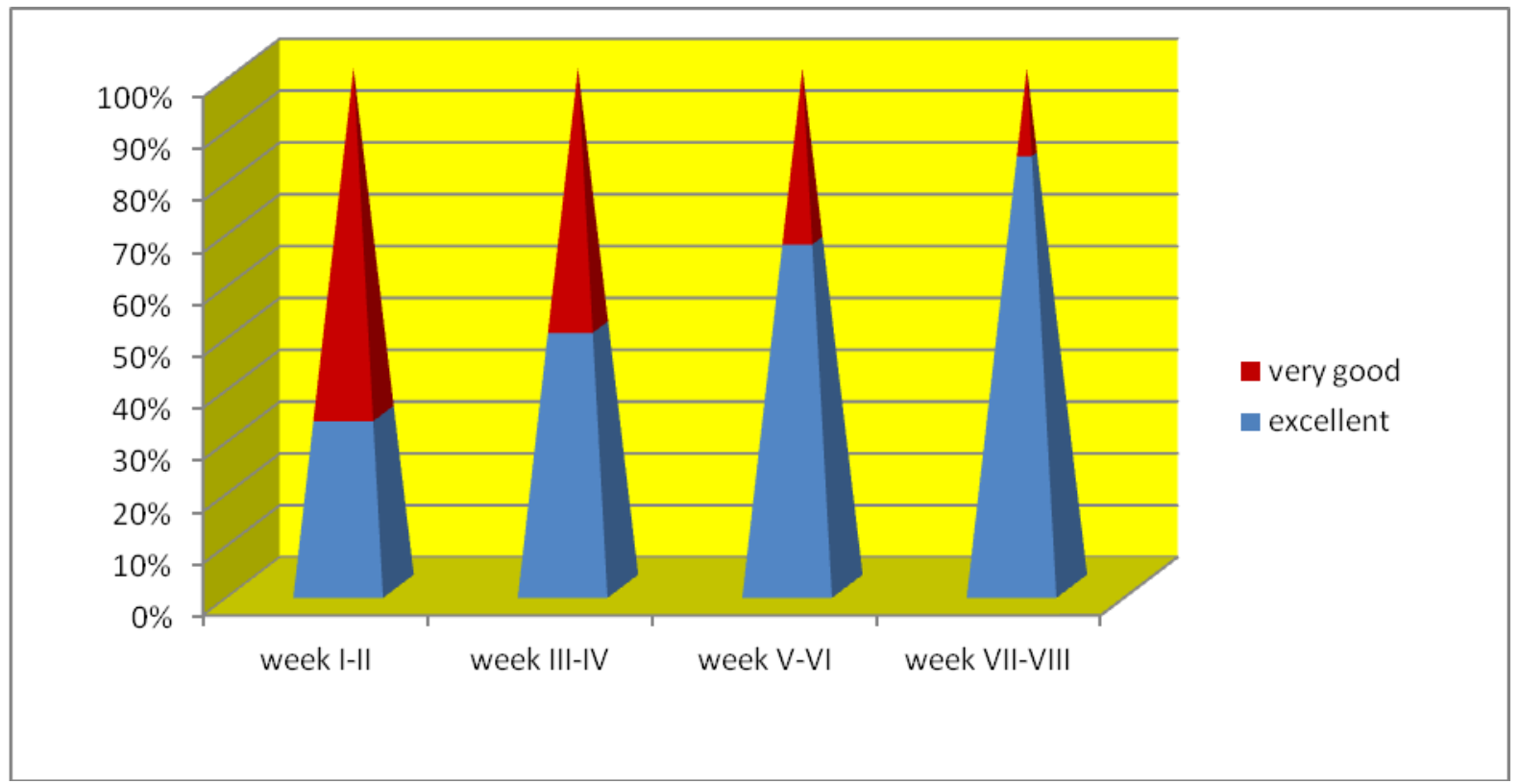

Fig. 1. Dynamics of motor capacity growth

Results obtained. After completing the training circuit and evaluating the level of motor capacity during the 2 control tests with a high degree of difficulty by intensifying the process of professional-applied physical training of operational staff, we found an increase in physical performance and improvement the response time during the interventions to the emergency situations, this being necessary to fulfill the attributions and missions that belong to the operative personnel of the inspectorate.

As can be seen in Figure 1, the results obtained by the non-commissioned officers evaluated after the tests show that an increasing group of employees obtained the grade "excellent" in the final test compared to the initial test, due to the intensification the process of professional-applicative physical training carried out within the subunits according to the scales and notes from Table 1 .

\section{Conclusions and recommendations:}

Following the application routes with a high degree of difficulty, we can say that the staff engaged in this activity has significantly improved their motor skills.

Therefore, one of the basic factors for performing many of the motor actions is the ability to exercise, which generally means the body's ability to perform a mechanical work as high as possible and maintain it for as long as shorter possible. 


\section{References:} DA.

1. Cârstea G. (2000). Teoria şi metodica educaţie fizice şi sportului. Bucureşti: Editura AN-

2. Chirazi M. (2002). Metode de cercetare în educaţie fizică şi sport: Curs. Iaşi: Editura Universităţii "Alexandru Ioan Cuza".

3. Dragnea A. şi colab. (2006). Educaţie fizică şi sport-teorie şi didactică. Bucureşti: Editura FEST.

4. Torje D.C. (2005). Teoria şi metodica pregătirii în domeniul educaţiei fizice a personalului M.A.I. Bucureşti: Editura Ministerului Afacerilor Interne.

5. Ordinul Ministrului Administrației și Internelor nr. 154 din 03.03.2004, privind activitățile de educație fizică și sport în M.A.I.;

6. Regulamentul pregătirii fizice (1984). București: MapN.

7. Metodica organizării și desfășurării pregătirii fizice a cadrelor din unitățile Ministerului de Interne (1989).

8. Legea 80 din 11 iulie 1995 privind statutul cadrelor militare cu modificările si completările ulterioare.

9. Ministerul de Interne, Comandamentul Pompierilor - Metodica instruţiei de specialitate a subunităţilor de pompieri (1989). Partea a II-a. Bucureşti.

10. Ordinului Inspectorului General al Inspectoratului General pentru Situaţii de Urgenţă nr. 7/IG din 21.03.2019 privind organizarea şi desfăşurarea pregătirii personalului operativ din subunităţile de intervenţie ale serviciilor de urgenţă profesioniste - ISU 06/2019. 